Article

\title{
Severe Heat Stress Resulted in High Coral Mortality on Maldivian Reefs following the 2015-2016 El Niño Event
}

\author{
Pia Bessell-Browne ${ }^{1}$, Hannah E. Epstein ${ }^{2}$, Nora Hall ${ }^{3}$, Patrick Buerger ${ }^{4,5}$ and Kathryn Berry ${ }^{6, *}$ \\ 1 CSIRO Oceans and Atmosphere, Castray Esplanade, Hobart, TAS 7000, Australia; \\ pia.bessell-browne@csiro.au \\ 2 Department of Microbiology, Oregon State University, Corvallis, OR 97331, USA; \\ epsteinh@oregonstate.edu \\ 3 College of Science and Engineering, James Cook University, Townsville, QLD 4811, Australia; \\ Noramhall@gmail.com \\ 4 CSIRO Synthetic Biology Future Science Platform, Land \& Water, Black Mountain, ACT 2601, Australia; \\ patrick.buerger@unimelb.edu.au \\ 5 School of BioSciences, The University of Melbourne, Parkville, VIC 3010, Australia \\ 6 Department of Fisheries and Oceans, Institute of Ocean Sciences, Sidney, BC V8L 4B2, Canada \\ * Correspondence: kathrynbberry@gmail.com
}

Citation: Bessell-Browne, P.;

Epstein, H.E.; Hall, N.; Buerger, P.;

Berry, K. Severe Heat Stress Resulted

in High Coral Mortality on Maldivian Reefs following the 2015-2016 El

Niño Event. Oceans 2021, 2, 233-245.

https://doi.org/

10.3390/oceans2010014

Academic Editor: Rupert Ormond

Received: 28 October 2020

Accepted: 22 February 2021

Published: 3 March 2021

Publisher's Note: MDPI stays neutral with regard to jurisdictional claims in published maps and institutional affiliations.

Copyright: (c) 2021 by the authors. Licensee MDPI, Basel, Switzerland. This article is an open access article distributed under the terms and conditions of the Creative Commons Attribution (CC BY) license (https:// creativecommons.org/licenses/by/ $4.0 /)$
Abstract: Coral cover worldwide has been declining due to heat stress caused by climate change. Here we report the impacts of the 2015-2016 El Niño mass coral bleaching event on the coral cover of reefs located on central and northern atolls of the Maldives. We surveyed six reef sites in the Alifu Alifu (Ari) and Baa (South Maalhosmadulu) Atolls using replicate $20 \mathrm{~m}$ benthic photo transects at two depths per reef site. Live and recently dead coral cover identified from images differed between reef sites and depth. Recently dead corals on average made up 33\% of the coral assemblage at shallow sites and $24 \%$ at deep sites. This mortality was significantly lower in massive corals than in branching corals, reaching an average of only $6 \%$ compared to $41 \%$, respectively. The best predictors of live coral cover were depth and morphology, with a greater percentage of live coral at deep sites and in massive corals. The same predictors best described the prevalence of recently dead coral, but showed inverse trends to live coral. However, there was high variability among reef sites, which could be attributed to additional local stressors. Coral bleaching and resulting coral mortalities, such as the ones reported here, are of particular concern for small island nations like the Maldives, which are reliant on coral reefs.

Keywords: Maldives; Indian Ocean; El Niño; mass coral bleaching; coral mortality; benthic cover

\section{Introduction}

Elevated seawater temperatures resulting from climate change are causing widespread coral bleaching events across tropical regions of the world [1-3]. Over the past 30 years the frequency and severity of these bleaching events have increased and they are now occurring on an unprecedented scale [1,4]. In 2015-2016, a severe El Niño event led to widespread coral bleaching across the Pacific and Indian Oceans [1,2,4-8], with some regions experiencing repeated heat stress events throughout this period (e.g., Chagos Archipelago [9], Great Barrier Reef (GBR) [2,10]). During the El Niño, some areas of the Pacific experienced extreme heat stress, reaching over 20 degree heating weeks (DHWs) [5], a metric representing accumulated heat stress over a 90-day window in comparison to historical maximum monthly means (MMMs) [10]. Although not quite as extreme, DHWs from the Western and Eastern Indian Ocean during the same period still greatly exceeded the bleaching threshold, with records ranging from four to 11 [11-13].

Coral bleaching occurs when corals expel their photosynthetic endosymbiotic algae (Symbiodiniaceae), often as a result of temperature stress, leaving a white skeleton visible through translucent tissue [14]. Corals may recover over time or coral mortality may occur 
if the algae cells are not regained and temperature stress conditions persist. Susceptibility to bleaching and mortality can vary among coral species due to a variety of factors, which include coral morphology $[15,16]$, history of stress or temperature exposure $[17,18]$, associated algal symbiont type [19-21], and the coral microbiome [22]. This variability in susceptibility can cause not only a loss in overall coral cover, but also a reduction in both the biodiversity and functional diversity of coral assemblages [23]. In severe cases bleaching and subsequent mass mortality events result in decreased larval supply and connectivity, which can result in phase shifts that are often from coral to macroalgal dominated reefs [24]. Other alternate states include sponge- or urchin-dominated reefs [25,26]. It becomes difficult for corals to re-populate reefs and reverse such phase shifts (reviewed in [27]), resulting in obvious changes to benthic and reef-associated pelagic assemblages across the reef ecosystem.

Mass coral bleaching events impact not only the health of the coral reef ecosystem, but also the human populations that may rely on artisanal fisheries, coastal protection, and ecotourism. Coral mortality can be particularly concerning for small island nations because reefs represent a lifeline that provides food and livelihood. Loss of coral in the ecosystem can decrease catches of artisanal reef fisheries and discourage tourism, ultimately impacting the food security and economy of local communities [28,29].

One such small island nation is the Republic of Maldives, located in the central equatorial Indian Ocean. The Maldives is made up of over 1000 islets situated within 26 atolls. It is the largest group of coral reefs in the Indian Ocean, hosting approximately 1100 reef-associated fish species and 250 species of coral [30]. The economy of the Maldives benefits from marine resources through tourism and ecosystem services such as coastal protection, food, and construction materials [31]. Thus, changes to the state of Maldivian reef health is of concern to the nation. During the 2015-2016 El Niño event, reefs in the Maldives experienced between four and 11 DHWs, suggesting considerable heat stress [32]. This resulted in widespread bleaching across the region [7,33-35], with bleaching observed in 73\% of corals from 0-13 m depth [12]. Here we document the effects of the 2015-2016 global bleaching event on the survival and mortality of coral communities in the northern atolls of the Maldives.

\section{Results}

Six coral reef sites were monitored in the Alifu Alifu and Baa Atolls in the Republic of Maldives (Figure 1) to assess post-bleaching coral mortality. The percentage of live coral cover at each coral reef site $(n=6)$ and depth was variable and ranged between $3 \%$ and $26 \%$ of substrate cover in December 2016, following the peak of the heating event that occurred in May of the same year (Figure 2). Of all the sites, live coral cover was lowest at Hurasdhoo, with an average of $3 \pm 4 \%$ (mean \pm standard error, $n=51$ ) at deep sites (Figure 2). No records were available for this site at shallow depths. All other sites had similar live coral cover at shallow depths, ranging from $13 \pm 8 \%(n=34)$ at Rasdhoo to $26 \pm 13 \%(n=51)$ at Dhonfanu (Figure 2). Live coral cover at depth had a similar range, from $13 \pm 14 \%(n=51)$ at Nika Point to $27 \pm 12 \%(n=51)$ at Dhonfanu (Figures 2 and 3). 


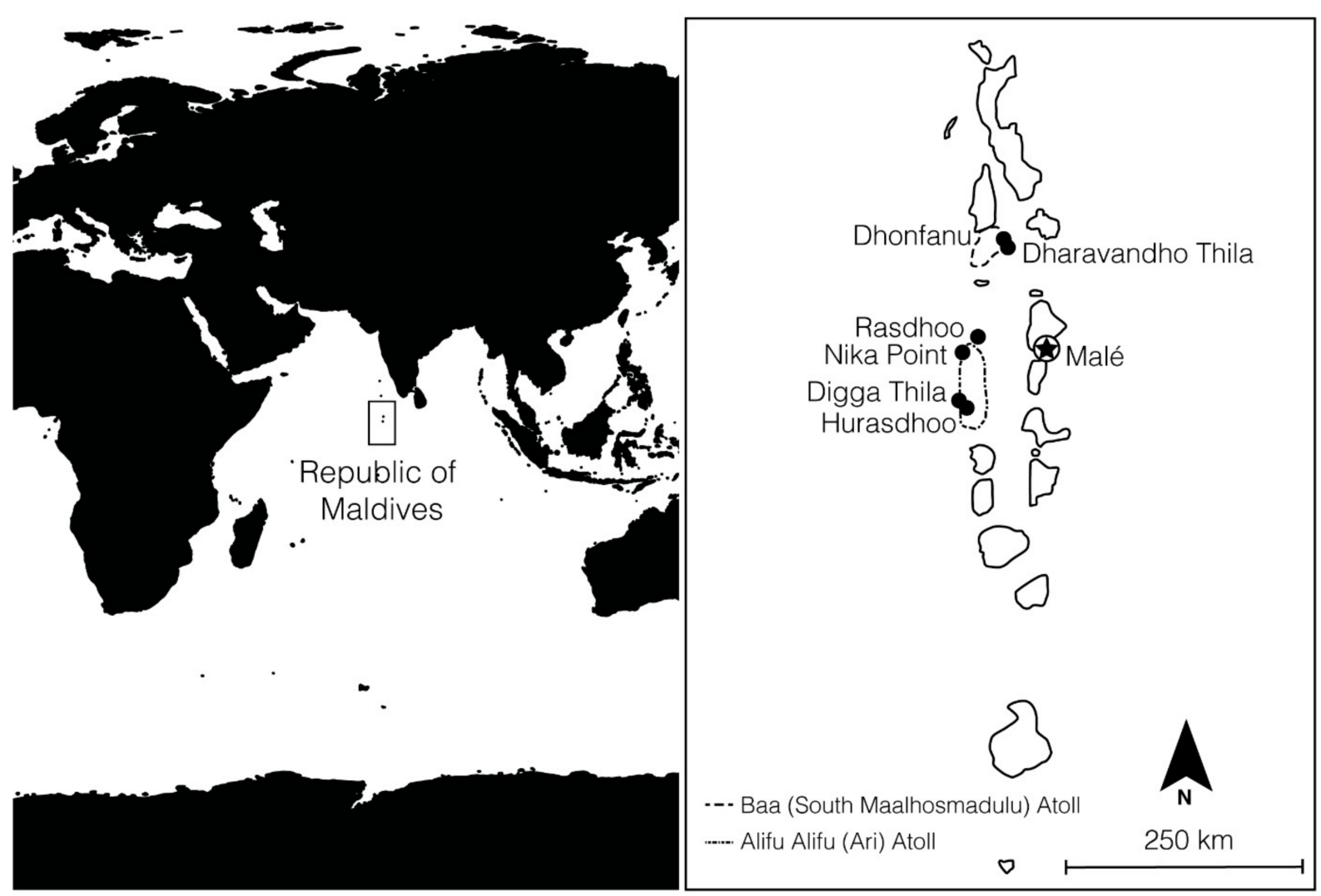

Figure 1. Reef site locations within the northern atolls (Baa and Alifu Alifu Atolls) of the Republic of Maldives. Sampling locations are marked with a black dot on the map.

Recently dead coral, classified as coral skeletons covered with turf algae but with the skeleton still intact, was also abundant at each of the sites surveyed (Figure 2). At shallow depths, this was as high as $54 \pm 19 \%(n=52)$ of the substrate cover at Digga Thila (Figure 2). The percentage of recently dead coral at shallow transects at all other sites ranged from $12 \pm 8 \%(n=50)$ at Nika Point to $40 \pm 14 \%(n=51)$ at Dhonfanu (Figure 2$)$. Of the deep transects, the percentage of recently dead coral was highest at Hurasdhoo, averaging $41 \pm 25 \%(n=51)$, although this was highly variable between transects and replicates (Figure 2).

Very few coral colonies were still bleached, with translucent live tissue covering the skeleton, at the time of data collection seven months after peak heat stress. The total substrate covered by bleached corals ranged from $0.1 \pm 0.7 \%(n=54)$ to $2.9 \pm 7.6 \%(n=54)$ across all reef sites and depths.

Modelling of variables influencing the percentage cover of live coral suggested that the best model fit was obtained when including additive effects of reef site, depth, and morphology (Table 1). When accounting for these variables, live coral cover was estimated to be considerably lower at Hurasdhoo ( $3 \%$ live cover, with confidence intervals (CI) of $2-5 \%)$, compared with all other reef sites, over which coral cover ranged from 18\% (15-22\% CI) to $29 \%$ (25-34\% CI) (Figure 4a). Mean live coral cover was found to be higher at deep rather than shallow sites, estimated to be $23 \%$ (19-27\% CI) and 16\% (13-19\% CI), respectively (Figure $4 \mathrm{~b}$ ). In addition, mean live coral cover was found to be greater in massive corals than branching corals, estimated to be $33 \%(27-39 \% \mathrm{CI})$ in massive corals and $6 \%(5-7 \% \mathrm{CI})$ in branching corals (Figure $4 \mathrm{c})$. 


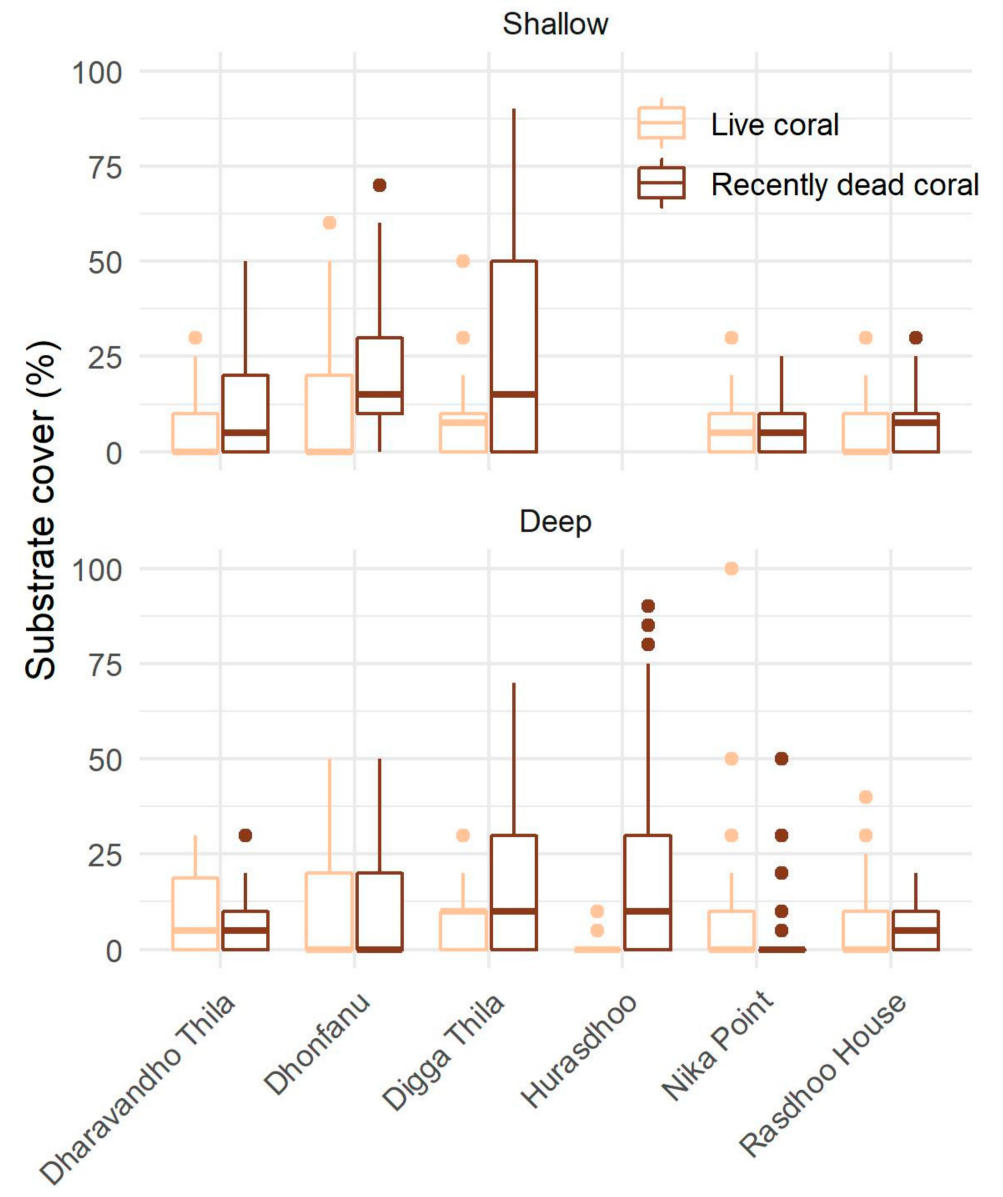

Figure 2. Box and whisper plot showing the percentage of substrate cover of live corals and recently dead corals at both shallow and deep transects at each of the six reef sites surveyed.
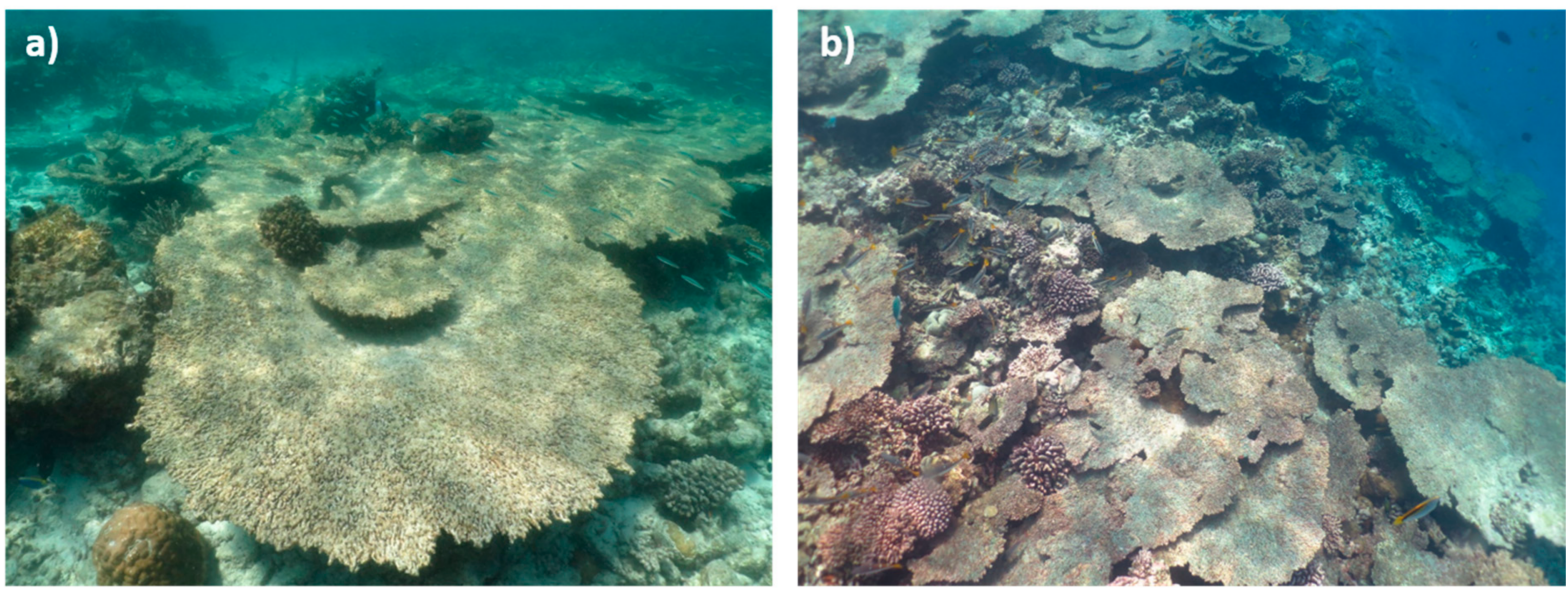

Figure 3. Extensive stands of dead corals (Acropora spp.) in the Maldives, where reefs exhibited high levels of coral mortality in December 2016 following the 2015-2016 El Niño mass coral bleaching event ((a) and (b)). 
Table 1. Generalised linear mixed effect model (GLMM) fit statistics investigating the most important variables influencing both (a) live coral and (b) recently dead coral. Shown are the number of parameters $(n)$, Akaike information criteria (AICc), $\delta$ AICc, and AICc weight $\left(\omega_{i}\right)$. The best fitting model is highlighted in bold.

\begin{tabular}{|c|c|c|c|c|c|}
\hline Coral Cover & Model & $n$ & AICc & $\delta \mathrm{AICc}$ & $\omega_{\mathrm{i}}$ \\
\hline \multirow[t]{8}{*}{ (a) Live coral } & $\begin{array}{l}\text { Reef site }+ \text { depth }+ \\
\text { morphology }\end{array}$ & 11 & 1013.3 & 0 & 1 \\
\hline & Reef site + morphology & 10 & 1036.7 & 23.31 & 0 \\
\hline & Depth + morphology & 6 & 1153 & 139.64 & 0 \\
\hline & Morphology & 5 & 1156.4 & 143.05 & 0 \\
\hline & Reef site + depth & 10 & 1523.5 & 510.12 & 0 \\
\hline & Reef site & 9 & 1537.7 & 524.31 & 0 \\
\hline & Depth & 5 & 1635.1 & 621.79 & 0 \\
\hline & Null & 4 & 1637 & 623.64 & 0 \\
\hline (b) Recently & $\begin{array}{l}\text { Reef site }+ \text { depth }+ \\
\text { morphology }\end{array}$ & 11 & 1034.7 & 0 & 1 \\
\hline \multirow[t]{7}{*}{ dead coral } & Reef site + morphology & 10 & 1056.2 & 21.53 & 0 \\
\hline & Depth + morphology & 6 & 1093 & 58.25 & 0 \\
\hline & Morphology & 5 & 1096.5 & 61.81 & 0 \\
\hline & Reef site + depth & 10 & 1177.8 & 143.12 & 0 \\
\hline & Reef site & 9 & 1193.5 & 158.75 & 0 \\
\hline & Depth & 5 & 1236.9 & 202.18 & 0 \\
\hline & Null & 4 & 1238.1 & 203.41 & 0 \\
\hline
\end{tabular}

(a) Reef

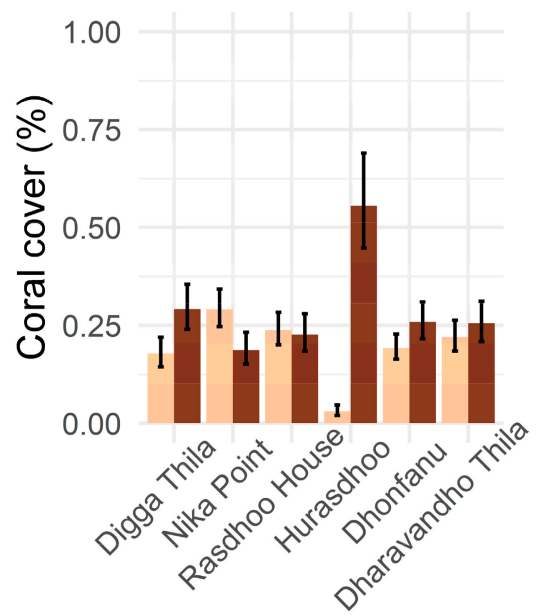

(b) Depth

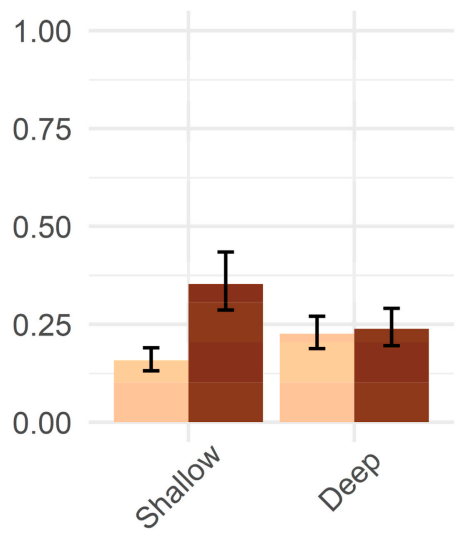

(c) Morphology

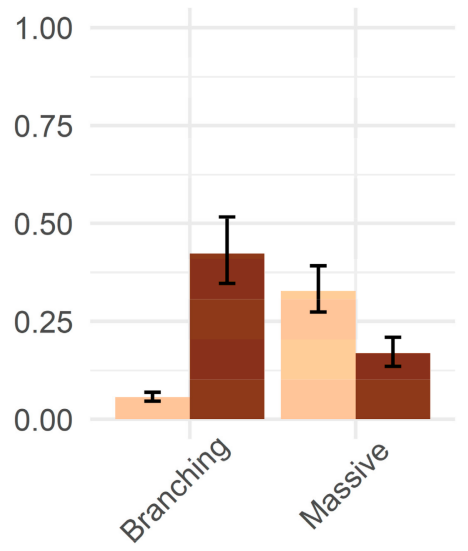

Figure 4. Predicted percentage of substrate cover of both live coral and recently dead coral by (a) reef, (b) depth, and (c) morphology, with $95 \%$ confidence intervals.

Modelling the cover of recently dead coral also suggested the best fitting model included additive effects of reef site, depth, and morphology (Table 1b). The percentage of dead coral cover at each reef site varied. The highest percentage was found at Hurasdhoo, with $56 \%( \pm 45-69 \%)$ recently dead coral cover, whereas the remainder of the reef sites ranged from $19 \%( \pm 15-23 \%)$ to $29 \%( \pm 24-36 \%)$ (Figure $4 a)$. Overall, there were more recently dead corals at shallow depths, with estimates of $35 \%( \pm 28-43 \%)$ compared to $24 \%( \pm 20-29 \%)$ at deep sites (Figure $4 \mathrm{~b})$. Estimates of recently dead massive corals were also lower than those for branching corals, with massive estimates of $17 \%( \pm 14-21 \%)$ and branching estimates of $42 \%$ ( $\pm 34-52 \%$ ) (Figure $4 \mathrm{c}$ ). The percentage of cover of recently dead corals was inverse to the trends observed for live coral cover (Figure 4). 


\section{Discussion}

\subsection{Bleaching and Mortality}

During the 2016 El Niño the Maldives experienced a severe bleaching event with the overall mean percentage of bleached corals (across 71 sites and depths ranging from 0-13 m) reaching 73\%, with some sites exhibiting close to 100\% bleaching [12]. Although the peak of the bleaching event occurred between mid-April and mid-June 2016 and some mortality was seen at this time, many colonies remained bleached for several months. Live mean coral cover was reduced to approximately $6-20 \%$ across the central and southern Maldives [33-35], with both lagoonal and oceanic reefs impacted [35]. Higher mortality was observed at reef sites in proximity to higher local population sizes, suggesting that these sites were more strongly impacted by human pressures (e.g., North and South Malé Atolls [35]). Coral reef sites investigated in the present study were exposed to comparatively lower human pressures (Baa and Alifu Alifu Atolls), but still exhibited extensive mortality (Figures 3 and 4), with mean live coral cover reduced to 3-27\%. The observed bleachinginduced mortality followed similar patterns as previously recorded bleaching severity in the area (see $[7,12,34])$; mortality was highest in shallow depths $(\sim 30 \%$ mortality) and among branching corals ( $40 \%$ mortality), especially Acropora spp.

Bleaching severity is considered to vary spatially (e.g., [36,37]) and to be influenced by microhabitat features [38]. Additionally, coral morphology is a factor and branching corals are more susceptible to bleaching and mortality during heat stress in comparison to massive corals $[15,39,40]$. Branching structures can help optimize light dispersion and reflection that may be important for maintaining colony health at depth or in normal light conditions. However, for colonies in shallow habitats where irradiance is naturally higher, this structure may cause supra-optimal irradiance conditions during heatwaves, accelerating or intensifying bleaching $[15,39,40]$. In contrast, massive corals have less structural complexity and have been found to have a higher resistance to bleaching, taking longer to bleach and experiencing less mortality [41]. Although branching corals did experience higher bleaching-induced mortality than massive corals in the present study, these mortality levels (approximately 40\%) were comparably lower than branching coral mortality in other areas of the Maldives in the aftermath of the 2016 El Niño event. North Malé (Kaafu) Atoll experienced 80\% mortality of Acropora spp., the dominant branching coral genus in the Maldives [12], and southern sheltered reefs exhibited $75 \%$ mortality in branching corals [33]. In a similar pattern, the Chagos Archipelago, situated south of the Maldives, lost 86\% of Acropora spp. cover (from 2-14\%) during the 2015-2016 thermal anomalies, shifting to a community dominated by Porites spp. post bleaching [9].

Interestingly, although branching corals are generally considered more susceptible than massive corals on mildly bleaching reefs, this pattern breaks down when reefs are exposed to severe bleaching: Some corals that are normally classified as thermotolerant (e.g., many massive species) can nevertheless become bleached under severe heat stress (e.g., [1]). This may suggest that the Maldives was not hit as hard by this El Niño event as some reefs in other areas around the globe. In support of this, although DHWs in the Maldives reached 11, which exceeds the proposed eight DHW mass bleaching threshold, other reefs around the globe reached much higher DHWs: up to 16 on the GBR and over 20 in the central Pacific [1,5]. Mortality in some of these areas was nearly 100\% [42]. The mortality recorded here on Maldivian reef sites still exceeded 50\%, and although this is less than what some of the hardest hit reefs globally experienced during the 2015-2016 El Niño, this remains a mass mortality event that can have major consequences for reef recovery.

\subsection{Potential for Recovery of Maldivian Reefs}

Maldivian coral reefs experienced severe bleaching in 1998 [43,44] and again in 2016 [12], and between these dates also endured a series of mild bleaching events in 2003, 2005, 2007, and 2010 [45-47]. During this recovery period, Maldivian reefs faced other disturbances, such as a tsunami in 2004 [48] and outbreaks of crown-of-thorns starfish (Acanthaster planci), both of which contributed to further coral mortality and influenced 
recovery capacity in the impacted localized areas [49]. Following the 1998 bleaching event, which resulted in mass mortality (90\%) of hard corals [50] and a near total disappearance of tabular coral [51], Maldivian reefs underwent a recovery trajectory that spanned the next 18 years. Initial mortality of acroporids (up to 90\% [51]) led to a shift in assemblage composition of coral cover, from Acropora-dominated to Porites-dominated, for the first eight-plus years of recovery [43,49,52,53]. By 2014, 15 years post bleaching, reefs in the region resembled pre-1998 bleaching assemblages, however, with an absence of species that had yet to recover [46,49]. After the 1998 bleaching event the constructional capacity (i.e., bioconstruction potential, carbonate deposition, and reef accretion) of Maldivian reefs was severely affected, with two to three years required for renewed carbonate deposition and 14-16 years required before accretion rates were high enough to ensure constratal (low-relief) growth [54].

Recovery of Maldivian reefs post 1998 bleaching event was slower than rates reported in the neighbouring Chagos Archipelago [49,55,56], which lacks local human threats and recovered in 10 years [9]. Slower recovery was likely related to the increased level of human pressures that Maldivian reefs experience (e.g., overexploitation of resources, pollution, and coastal development) that influence the success of coral reef recovery, overall coral reef health, and resilience (e.g., [57,58]). Environmental degradation associated with humaninduced pressures have increased in the Maldives, particularly related to local population growth, coastal development, land reclamation works, and tourism [59-62]. Whereas local populations reached 344,023 in 2014, increases in the numbers of tourists grew by $400 \%$ between 1997 and 2019, reaching 1.5 million visitors in 2019 [35].

Following the 2016 bleaching event, coral mortality was greater at coral reefs exposed to increased human pressures (e.g., North and South Malé [35]). For example, reefs in proximity to land reclamation projects experienced four-fold increases in sedimentation loads and exhibited significant reductions in live coral cover post bleaching event in comparison to reefs not impacted by both land reclamation activities and bleaching [62]. Land reclamation and associated dredging (Figure 5a) and dumping activities contribute to increased suspended sediments and deposited sediment loads (i.e., sedimentation). Increased suspended sediments reduce light levels required by corals to photosynthesize [63-65], but even low levels of sediment or other particulate deposition reduces suitable reef substrate for coral recruitment [66,67]. Bleached corals are less capable of removing sediments from their tissue surface [68], resulting in prolonged smothering and increased energy expenditure to clear sediments [69,70]. Recent investigations into cumulative impacts of increased suspended sediments and bleaching events indicate that these impacts can be synergistic when suspended sediments are at high concentrations, resulting in greater mortality than would be observed with either individual event [71].
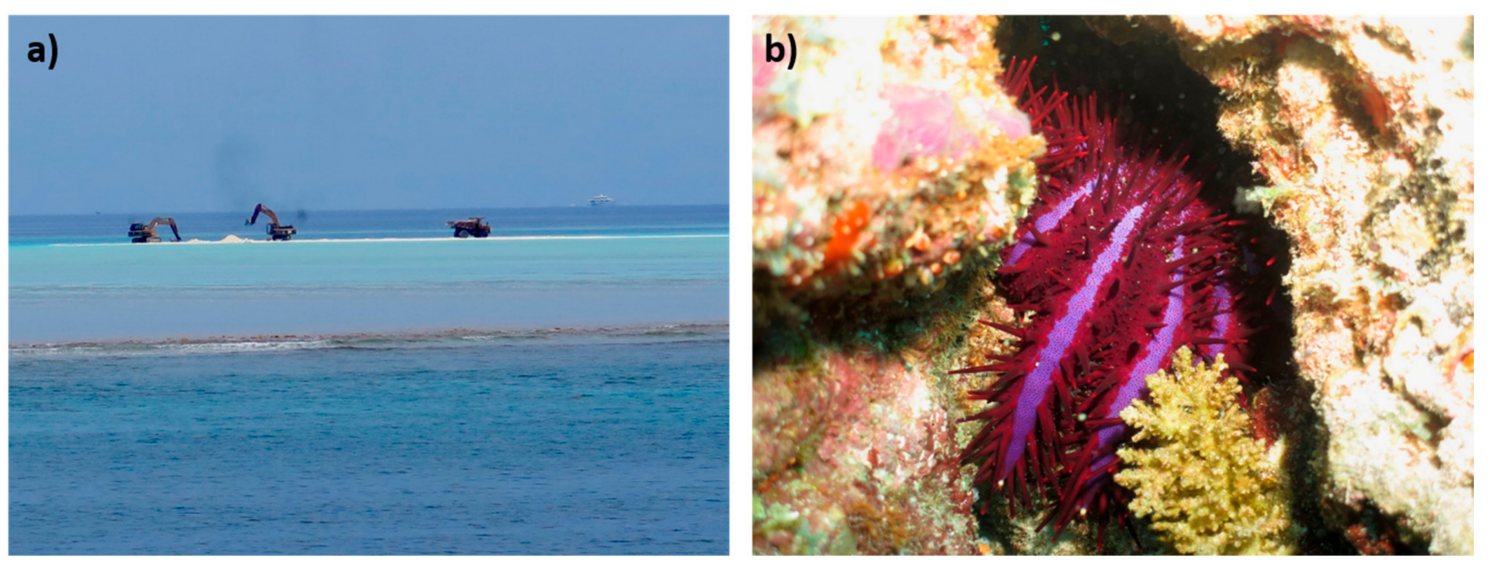

Figure 5. Maldivian coral reefs are exposed to local disturbances such as coastal development and land reclamation projects (a) and crown-of-thorns starfish that prey on corals (b). These additional pressures and thermal stress events may contribute to cumulative pressures on coral reef health and influence reef resilience and recovery. 
Although land reclamation activities were not taking place near the coral reef sites surveyed in the present study, two crown-of-thorns starfish (Figure 5b) were observed at Hurasdhoo, which exhibited the highest coral mortality. Coral mortality caused by bleaching can be compounded and/or exacerbated by crown-of-thorns starfish, which favor branching corals as prey [34], and likely contributed to the higher reported mortality at this reef site.

The 2016 bleaching event resulted in lower coral mortality than the 1998 event and initial recovery has been faster [54]. By May 2017 hard coral cover had increased to a mean of approximately 30\% (at eight reef sites surveyed across the atolls of Ari Felidhoo, Gaafu Alifu (Suvadiva), North Malé, South Malé, Rasdhoo, and Thoddoo), however, Acropora spp. had yet to show evidence of recovery at that time [54]. Current research shows that recovery trajectories are following different trends post 1998 and post 2016 bleaching events [54]. These differences are not surprising given that local human pressures have increased while pre-bleaching coral assemblage and reef health differed. Though faster recovery rates are positive for these reefs, the projected increases in both the frequency and intensity of bleaching events, lengthy recovery timeframes, and local disturbances suggest that Maldivian reefs may not have time to recover before the next severe bleaching event $[35,54]$. It is therefore critical that policies and management actions are created and implemented that focus on reducing local and regional stressors. Effective management initiatives will be crucial in facilitating the future resilience of both Maldivian reefs and the livelihoods of those that depend on them.

\section{Materials and Methods}

\subsection{Field Surveys}

Coral mortality surveys were conducted from 2-8 December, 2016, approximately 7 months after the peak thermal stress occurred [7]. Six coral reef sites were monitored in the Alifu Alifu and Baa Atolls (Figure 1) in the Republic of Maldives using modified Reef Check International protocols [72]. In brief, within each reef, coral cover was surveyed on both the reef crest and reef slope of lagoon reefs. Three $20 \mathrm{~m}$ transect lines were surveyed at each depth, with $5 \mathrm{~m}$ between each transect (for a total of $n=6$ transects per reef site, $60 \mathrm{~m}$ length per depth). Shallow transects were placed along a $4-5.5 \mathrm{~m}$ contour (average depth $=4.9 \mathrm{~m} \pm 0.2$ ), and deep transects were placed at a 9-11 $\mathrm{m}$ contour (average depth $=10.7 \mathrm{~m} \pm 0.3$ ). Photos were taken at $1 \mathrm{~m}$ interval points along each transect from approximately $1 \mathrm{~m}$ above the substrate and $0.5 \mathrm{~m}$ in each direction from the interval point. The shallow transect of one reef, Hurasdhoo House Reef, was omitted from analysis due to poor image quality.

\subsection{Image Analyses}

Photographs taken along each transect were assessed to determine the percentage of cover of benthic organisms and substrate. Each photograph contained approximately one square meter of the substrate. A grid was placed over each image to aid in the calculation of substrate proportions. In every photograph each component of the benthic substrate was recorded as a percentage of the total area and rounded to the nearest $5 \%$. The categories that were used to determine benthic substrate included the 10 Reef Check International substrate categories, including hard coral, soft coral, recently dead coral, nutrient indicator algae, sponge, rock, rubble, sand, silt, and other [72].

Only data in the hard coral category were analysed for the purpose of this study. Insufficient numbers of some growth forms in the photographs limited the morphological categories to two: branching and massive, within the first of which corymbrose corals were grouped with branching and within the second of which sub-massive corals were grouped with massive (see Table 2). 
Table 2. Categories used to characterize benthic substrate during image analysis.

\begin{tabular}{|c|c|}
\hline Category & Description \\
\hline Live hard coral & $\begin{array}{c}\text { Live coral that is pigmented. Split into three morphology } \\
\text { categories. }\end{array}$ \\
\hline Bleached hard coral & $\begin{array}{c}\text { Live coral that appears white or fluorescent in color and has } \\
\text { lost normal pigment. Tissue has not been colonised by any } \\
\text { algae and is therefore considered to still be alive. }\end{array}$ \\
\hline Recently dead hard coral & $\begin{array}{c}\text { Coral colonies that have recently died. Skeletons had a light } \\
\text { covering of turf algae that distinguish them from } \\
\text { translucent tissue in bleached coral and pigmented tissue in } \\
\text { live coral. Algae cover was not well established and there } \\
\text { was no breakdown of skeletal structure, suggesting coral } \\
\text { mortality was recent. }\end{array}$ \\
\hline
\end{tabular}

Each of the hard coral categories were grouped by growth form and health status, including live branching hard coral (BC), massive hard coral (MC), and hard coral of other growth forms (HC). Those corals that were visibly bleached with translucent tissue covering their skeleton were classified as bleached branching corals (BBC), bleached massive corals (BBM), and bleached corals of other growth forms (BHC). Those corals that were recently dead were also classified into their respective growth forms, including recently dead branching corals (RDBC), recently dead massive corals (RDMC), and other recently dead corals (RDHC).

Each of the hard coral categories used in the analysis are illustrated in Figure 6. These photographs illustrate the specification of recently dead coral in both massive and branching colonies as opposed to coral that has been dead for an extended period that has since turned to rock or rubble (Figure 6). Examples are included from both shallow and deep transects across various reef sites (Figure 6).

\subsection{Statistical Analyses}

To assess the impact of reef site, depth, and morphology on the percentage of cover of live and recently dead coral, data were analysed using generalised linear mixed models (GLMM, R version 3.6.3 [73]). The influence of reef, morphology, and depth was investigated using a full subsets model selection approach [74]. Following convention, the simplest model with the lowest Akaike information criterion was considered optimal [74]. A null model with only the intercept and random effect was included to determine whether any of the included variables were useful predictors of coral cover. The percentage of live or recently dead hard coral was modelled in relation to reef site, coral morphology, and transect depth, with transect included as a random effect. The model used a Tweedie distribution with a log link and was modelled using the glmmTMB function within the glmmTMB package [75]. 


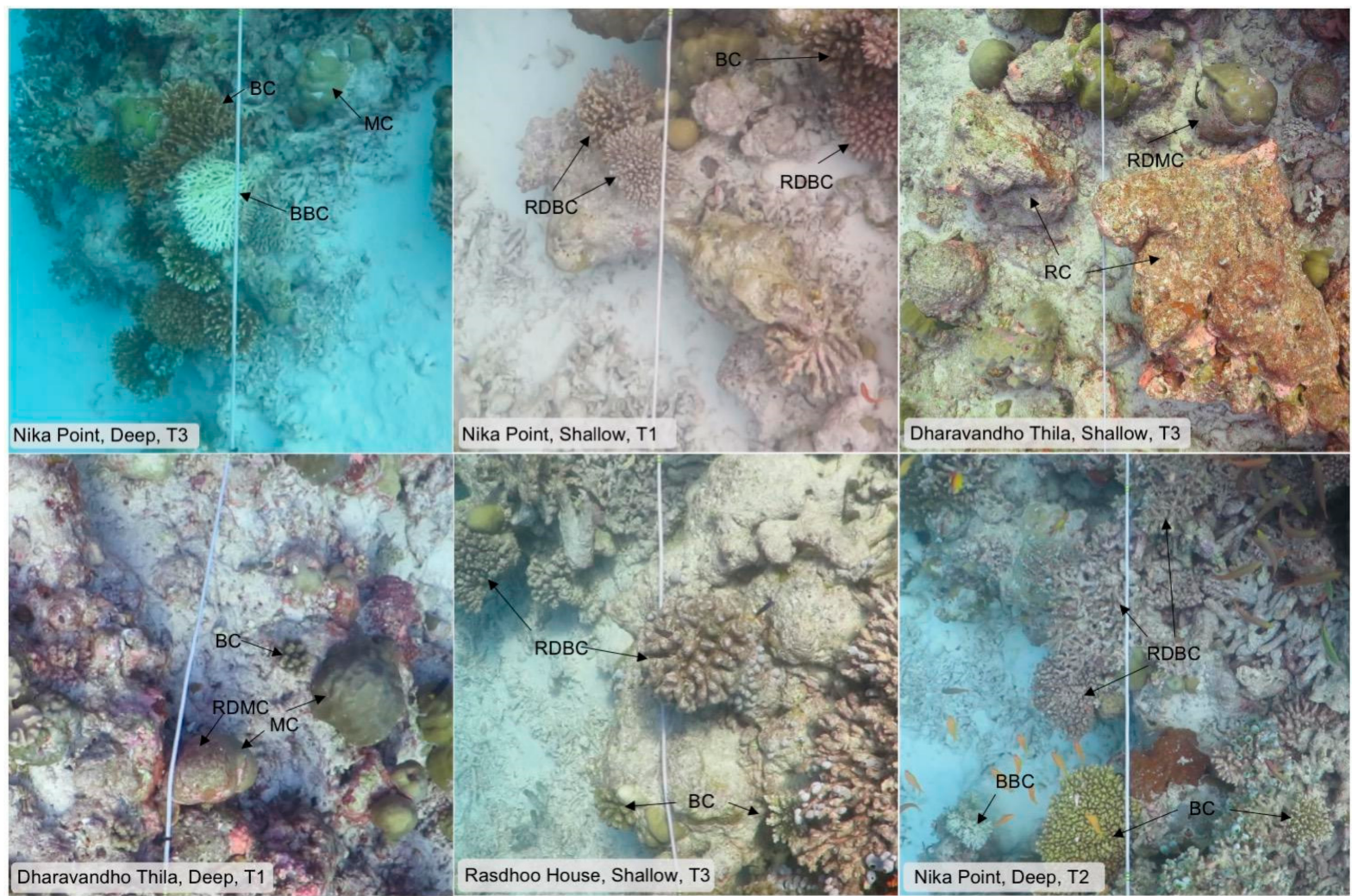

Figure 6. Examples of different coral health categories. The legend on each image indicates the site name (see Figure 1), transect depth (either deep or shallow), and number (T1, T2, or T3), along with the recorded coral health category. Coral health abbreviations include live branching coral (BC), bleached branching coral (BBC), recently dead branching coral (RDBC), live massive coral (MC), and recently dead massive coral (RDMC).

Author Contributions: K.B. and N.H. designed the study. P.B.-B., K.B. and P.B. processed the data. P.B.-B. and H.E.E. analysed the data. All authors contributed to the writing and review of the manuscript. There are no competing or conflicting interests. All authors have read and agreed to the published version of the manuscript.

Funding: This research received no external funding.

Data Availability Statement: The data presented in this study are available on request from the corresponding author.

Acknowledgments: This research was conducted with the support of The Hydrous NGO. We thank Hassan Hameez, Abdul Sattar Hassan, Kate Malmgren, Rick Miskiv, and Erika Woolsey for their help with field surveys and trip logistics.

Conflicts of Interest: The authors declare no conflict of interest.

\section{References}

1. Hughes, T.P.; Kerry, J.T.; Álvarez-Noriega, M.; Álvarez-Romero, J.G.; Anderson, K.D.; Baird, A.H.; Babcock, R.C.; Beger, M.; Bellwood, D.R.; Berkelmans, R.; et al. Global Warming and Recurrent Mass Bleaching of Corals. Nature 2017, 543, $373-377$. [CrossRef] [PubMed]

2. Hughes, T.P.; Anderson, K.D.; Connolly, S.R.; Heron, S.F.; Kerry, J.T.; Lough, J.M.; Baird, A.H.; Baum, J.K.; Berumen, M.L.; Bridge, T.C.; et al. Spatial and Temporal Patterns of Mass Bleaching of Corals in the Anthropocene. Science 2018, 359, 80-83. [CrossRef]

3. Heron, S.F.; Maynard, J.A.; Van Hooidonk, R.; Eakin, C.M. Warming Trends and Bleaching Stress of the World's Coral Reefs 1985-2012. Sci. Rep. Nat. Publ. Group Lond. 2016, 6, 38402. [CrossRef] [PubMed]

4. Eakin, C.M.; Sweatman, H.P.A.; Brainard, R.E. The 2014-2017 Global-Scale Coral Bleaching Event: Insights and Impacts. Coral Reefs 2019, 38, 539-545. [CrossRef] 
5. $\quad$ Barkley, H.C.; Cohen, A.L.; Mollica, N.R.; Brainard, R.E.; Rivera, H.E.; DeCarlo, T.M.; Lohmann, G.P.; Drenkard, E.J.; Alpert, A.E.; Young, C.W.; et al. Repeat Bleaching of a Central Pacific Coral Reef over the Past Six Decades (1960-2016). Commun. Biol. 2018, 1, 177. [CrossRef]

6. Monroe, A.A.; Ziegler, M.; Roik, A.; Röthig, T.; Hardenstine, R.S.; Emms, M.A.; Jensen, T.; Voolstra, C.R.; Berumen, M.L. In Situ Observations of Coral Bleaching in the Central Saudi Arabian Red Sea during the 2015/2016 Global Coral Bleaching Event. PLoS ONE 2018, 13, e0195814. [CrossRef]

7. Cowburn, B.; Moritz, C.; Grimsditch, G.; Solandt, J. Evidence of Coral Bleaching Avoidance, Resistance and Recovery in the Maldives during the 2016 Mass-Bleaching Event. Mar. Ecol. Prog. Ser. 2019, 626, 53-67. [CrossRef]

8. McClanahan, T.R.; Darling, E.S.; Maina, J.M.; Muthiga, N.A.; 'agata, S.D.; Jupiter, S.D.; Arthur, R.; Wilson, S.K.; Mangubhai, S.; Nand, Y.; et al. Temperature Patterns and Mechanisms Influencing Coral Bleaching during the 2016 El Niño. Nat. Clim. Change 2019, 9, 845-851. [CrossRef]

9. Head, C.E.I.; Bayley, D.T.I.; Rowlands, G.; Roche, R.C.; Tickler, D.M.; Rogers, A.D.; Koldewey, H.; Turner, J.R.; Andradi-Brown, D.A. Coral Bleaching Impacts from Back-to-Back 2015-2016 Thermal Anomalies in the Remote Central Indian Ocean. Coral Reefs 2019, 38, 605-618. [CrossRef]

10. Raymundo, L.J.; Burdick, D.; Hoot, W.C.; Miller, R.M.; Brown, V.; Reynolds, T.; Gault, J.; Idechong, J.; Fifer, J.; Williams, A. Successive Bleaching Events Cause Mass Coral Mortality in Guam, Micronesia. Coral Reefs 2019, 38, 677-700. [CrossRef]

11. Le Nohaï, M.; Ross, C.L.; Cornwall, C.E.; Comeau, S.; Lowe, R.; McCulloch, M.T.; Schoepf, V. Marine Heatwave Causes Unprecedented Regional Mass Bleaching of Thermally Resistant Corals in Northwestern Australia. Sci. Rep. 2017, 7, 14999. [CrossRef]

12. Ibrahim, N.; Mohamed, M.; Basheer, A.; Haleem, I.; Nistharan, F.; Schmidt, A.; Naeem, R.; Abdulla, A.; Grimsditch, G. Status of Coral Bleaching in the Maldives 2016; Maldives Marine Research Centre: Malé, Maldives, 2017; pp. 1-47.

13. Cerutti, J.M.B.; Burt, A.J.; Haupt, P.; Bunbury, N.; Mumby, P.J.; Schaepman-Strub, G. Impacts of the 2014-2017 Global Bleaching Event on a Protected Remote Atoll in the Western Indian Ocean. Coral Reefs 2020, 39, 15-26. [CrossRef]

14. Glynn, P.W. Widespread Coral Mortality and the 1982-83 El Niño Warming Event. Environ. Conserv. 1984, 11, 133-146. [CrossRef]

15. Marcelino, L.A.; Westneat, M.W.; Stoyneva, V.; Henss, J.; Rogers, J.D.; Radosevich, A.; Turzhitsky, V.; Siple, M.; Fang, A.; Swain, T.D.; et al. Modulation of Light-Enhancement to Symbiotic Algae by Light-Scattering in Corals and Evolutionary Trends in Bleaching. PLoS ONE 2013, 8, e61492. [CrossRef] [PubMed]

16. Smith, H.; Epstein, H.; Torda, G. The Molecular Basis of Differential Morphology and Bleaching Thresholds in Two Morphs of the Coral Pocillopora Acuta. Sci. Rep. 2017, 7, 10066. [CrossRef]

17. Grottoli, A.G.; Warner, M.E.; Levas, S.J.; Aschaffenburg, M.D.; Schoepf, V.; McGinley, M.; Baumann, J.; Matsui, Y. The Cumulative Impact of Annual Coral Bleaching Can Turn Some Coral Species Winners into Losers. Glob. Chang. Biol. 2014, 20, $3823-3833$. [CrossRef] [PubMed]

18. Safaie, A.; Silbiger, N.J.; McClanahan, T.R.; Pawlak, G.; Barshis, D.J.; Hench, J.L.; Rogers, J.S.; Williams, G.J.; Davis, K.A. High Frequency Temperature Variability Reduces the Risk of Coral Bleaching. Nat. Commun. 2018, 9, 1-12. [CrossRef]

19. Berkelmans, R.; van Oppen, M.J.H. The Role of Zooxanthellae in the Thermal Tolerance of Corals: A 'Nugget of Hope' for Coral Reefs in an Era of Climate Change. Proc. R. Soc. B Biol. Sci. 2006, 273, 2305-2312. [CrossRef] [PubMed]

20. Boulotte, N.M.; Dalton, S.J.; Carroll, A.G.; Harrison, P.L.; Putnam, H.M.; Peplow, L.M.; van Oppen, M.J. Exploring the Symbiodinium Rare Biosphere Provides Evidence for Symbiont Switching in Reef-Building Corals. ISME J. 2016, 10, $2693-2701$. [CrossRef]

21. Carballo-Bolaños, R.; Denis, V.; Huang, Y.-Y.; Keshavmurthy, S.; Chen, C.A. Temporal Variation and Photochemical Efficiency of Species in Symbiodinaceae Associated with Coral Leptoria Phrygia (Scleractinia; Merulinidae) Exposed to Contrasting Temperature Regimes. PLoS ONE 2019, 14, e0218801. [CrossRef] [PubMed]

22. Ziegler, M.; Grupstra, C.G.B.; Barreto, M.M.; Eaton, M.; BaOmar, J.; Zubier, K.; Al-Sofyani, A.; Turki, A.J.; Ormond, R.; Voolstra, C.R. Coral Bacterial Community Structure Responds to Environmental Change in a Host-Specific Manner. Nat. Commun. Lond. 2019, 10, 1-11. [CrossRef]

23. Cadotte, M.W. The New Diversity: Management Gains through Insights into the Functional Diversity of Communities. J. Appl. Ecol. 2011, 48, 1067-1069. [CrossRef]

24. Hughes, T.P.; Baird, A.H.; Bellwood, D.R.; Card, M.; Connolly, S.R.; Folke, C.; Grosberg, R.; Hoegh-Guldberg, O.; Jackson, J.B.C.; Kleypas, J.; et al. Climate Change, Human Impacts, and the Resilience of Coral Reefs. Science 2003, 301, 929-933. [CrossRef]

25. Norström, A.; Nyström, M.; Lokrantz, J.; Folke, C. Alternative States on Coral Reefs: Beyond Coral-Macroalgal Phase Shifts. Mar. Ecol. Prog. Ser. 2009, 376, 295-306. [CrossRef]

26. Chaves-Fonnegra, A.; Riegl, B.; Zea, S.; Lopez, J.V.; Smith, T.; Brandt, M.; Gilliam, D.S. Bleaching Events Regulate Shifts from Corals to Excavating Sponges in Algae-Dominated Reefs. Glob. Chang. Biol. 2018, 24, 773-785. [CrossRef] [PubMed]

27. Graham, N.A.; Bellwood, D.R.; Cinner, J.E.; Hughes, T.P.; Norström, A.V.; Nyström, M. Managing Resilience to Reverse Phase Shifts in Coral Reefs. Front. Ecol. Environ. 2013, 11, 541-548. [CrossRef]

28. Pratchett, M.S.; Hoey, A.S.; Wilson, S.K. Reef Degradation and the Loss of Critical Ecosystem Goods and Services Provided by Coral Reef Fishes. Curr. Opin. Environ. Sustain. 2014, 7, 37-43. [CrossRef]

29. Rogers, A.; Blanchard, J.L.; Mumby, P.J. Fisheries Productivity under Progressive Coral Reef Degradation. J. Appl. Ecol. 2018, 55, 1041-1049. [CrossRef] 
30. Naseer, A.; Hatcher, B.G. Inventory of the Maldives? Coral Reefs Using Morphometrics Generated from Landsat ETM+ Imagery. Coral Reefs 2004, 23, 161-168. [CrossRef]

31. Agardy, T.; Hicks, F.; Nistharan, F.; Fisam, A.; Schmidt, A.; Grimsditch, G. Ecosystem Services Assessment of North Ari Atoll Maldives; IUCN: Gland, Switzerland, 2017.

32. Liu, G.; Rauenzahn, J.; Heron, S.; Eakin, C.M.; Skirving, W.; Christensen, T.; Strong, A.; Li, J. NOAA Coral Reef Watch 50 Km Satellite Sea Surface Temperature-Based Decision Support System for Coral Bleaching Management. NOAA Tech. Rep. NESDIS 2013, 143, 41 .

33. Perry, C.T.; Morgan, K.M. Post-Bleaching Coral Community Change on Southern Maldivian Reefs: Is There Potential for Rapid Recovery? Coral Reefs 2017, 36, 1189-1194. [CrossRef]

34. Pisapia, C.; Burn, D.; Pratchett, M.S. Changes in the Population and Community Structure of Corals during Recent Disturbances (February 2016-October 2017) on Maldivian Coral Reefs. Sci. Rep. 2019, 9, 1-12. [CrossRef]

35. Montefalcone, M.; Morri, C.; Bianchi, C.N. Influence of Local Pressures on Maldivian Coral Reef Resilience Following Repeated Bleaching Events, and Recovery Perspectives. Front. Mar. Sci. 2020, 7, 587. [CrossRef]

36. Penin, L.; Adjeroud, M.; Schrimm, M.; Lenihan, H.S. High Spatial Variability in Coral Bleaching around Moorea (French Polynesia): Patterns across Locations and Water Depths. C. R. Biol. 2007, 330, 171-181. [CrossRef]

37. Done, T.; Wooldridge, S. Learning to Predict Large-Scale Coral Bleaching from Past Events: A Bayesian Approach Using Remotely Sensed Data, in-Situ Data, and Environmental Proxies. Coral Reefs 2004, 23, 96-108. [CrossRef]

38. Hoogenboom, M.O.; Frank, G.E.; Chase, T.J.; Jurriaans, S.; Álvarez-Noriega, M.; Peterson, K.; Critchell, K.; Berry, K.L.E.; Nicolet, K.J.; Ramsby, B.; et al. Environmental Drivers of Variation in Bleaching Severity of Acropora Species during an Extreme Thermal Anomaly. Front. Mar. Sci. 2017, 4, 376. [CrossRef]

39. Kaniewska, P.; Anthony, K.R.N.; Hoegh-Guldberg, O. Variation in Colony Geometry Modulates Internal Light Levels in Branching Corals, Acropora Humilis and Stylophora Pistillata. Mar. Biol. 2008, 155, 649-660. [CrossRef]

40. Swain, T.D.; DuBois, E.; Gomes, A.; Stoyneva, V.P.; Radosevich, A.J.; Henss, J.; Wagner, M.E.; Derbas, J.; Grooms, H.W.; Velazquez, E.M.; et al. Skeletal Light-Scattering Accelerates Bleaching Response in Reef-Building Corals. BMC Ecol. 2016, 16, 10. [CrossRef]

41. Baird, A.H.; Marshall, P. Mortality, Growth and Reproduction in Scleractinian Corals Following Bleaching on the Great Barrier Reef. Mar. Ecol. Prog. Ser. 2002, 237, 133-141. [CrossRef]

42. Vargas-Ángel, B.; Huntington, B.; Brainard, R.E.; Venegas, R.; Oliver, T.; Barkley, H.; Cohen, A. El Niño-Associated Catastrophic Coral Mortality at Jarvis Island, Central Equatorial Pacific. Coral Reefs 2019, 38, 731-741. [CrossRef]

43. McClanahan, T.R. Bleaching Damage and Recovery Potential of Maldivian Coral Reefs. Mar. Pollut. Bull. 2000, 40, 587-597. [CrossRef]

44. Edwards, A.J.; Clark, S.; Zahir, H.; Rajasuriya, A.; Naseer, A.; Rubens, J. Coral Bleaching and Mortality on Artificial and Natural Reefs in Maldives in 1998, Sea Surface Temperature Anomalies and Initial Recovery. Mar. Pollut. Bull. 2001, 42, 7-15. [CrossRef]

45. Tkachenko, K.S. The Northernmost Coral Frontier of the Maldives: The Coral Reefs of Ihavandippolu Atoll under Long-Term Environmental Change. Mar. Environ. Res. 2012, 82, 40-48. [CrossRef]

46. Morri, C.; Montefalcone, M.; Lasagna, R.; Gatti, G.; Rovere, A.; Parravicini, V.; Baldelli, G.; Colantoni, P.; Bianchi, C.N. Through Bleaching and Tsunami: Coral Reef Recovery in the Maldives. Mar. Pollut. Bull. 2015, 98, 188-200. [CrossRef]

47. McClanahan, T.R.; Muthiga, N.A. Community Change and Evidence for Variable Warm-Water Temperature Adaptation of Corals in Northern Male Atoll, Maldives. Mar. Pollut. Bull. 2014, 80, 107-113. [CrossRef] [PubMed]

48. Goffredo, S.; Piccinetti, C.; Zaccanti, F. Tsunami Survey Expedition: Preliminary Investigation of Maldivian Coral Reefs Two Weeks after the Event. Environ. Monit. Assess. 2007, 131, 95-105. [CrossRef] [PubMed]

49. Pisapia, C.; Burn, D.; Yoosuf, R.; Najeeb, A.; Anderson, K.D.; Pratchett, M.S. Coral Recovery in the Central Maldives Archipelago since the Last Major Mass-Bleaching, in 1998. Sci. Rep. 2016, 6, 34720. [CrossRef]

50. Bianchi, C.N.; Morri, C.; Pichon, M.; Benzoni, F.; Colantoni, P.; Baldelli, G.; Sandrini, M. Dynamics and Pattern of Coral Recolonization Following the 1998 Bleaching Event in the Reefs of the Maldives. In Proceedings of the 10th International Coral Reef Symposium, Okinawa, Japan, 28 June-2 July 2004; Japanese Coral Reef Society: Tokyo, Japan, 2004; pp. 30-37.

51. Schuhmacher, H.; Loch, K.; Loch, W.; See, W.R. The Aftermath of Coral Bleaching on a Maldivian Reef-a Quantitative Study. Facies 2005, 51, 80-92. [CrossRef]

52. Goreau, T.; McClanahan, T.; Hayes, R.; Strong, A. Conservation of Coral Reefs after the 1998 Global Bleaching Event. Conserv. Biol. 2000, 14, 5-15. [CrossRef]

53. Lasagna, R.; Albertelli, G.; Giovannetti, E.; Grondona, M.; Milani, A.; Morri, C.; Bianchi, C.N. Status of Maldivian Reefs Eight Years after the 1998 Coral Mass Mortality. Chem. Ecol. 2008, 24, 67-72. [CrossRef]

54. Montefalcone, M.; Morri, C.; Bianchi, C.N. Long-Term Change in Bioconstruction Potential of Maldivian Coral Reefs Following Extreme Climate Anomalies. Glob. Chang. Biol. 2018, 24, 5629-5641. [CrossRef]

55. Sheppard, C.R.C.; Harris, A.; Sheppard, A.L.S. Archipelago-Wide Coral Recovery Patterns since 1998 in the Chagos Archipelago, Central Indian Ocean. Mar. Ecol. Prog. Ser. 2008, 362, 109-117. [CrossRef]

56. Graham, N.A.J.; McClanahan, T.R.; MacNeil, M.A.; Wilson, S.K.; Polunin, N.V.C.; Jennings, S.; Chabanet, P.; Clark, S.; Spalding, M.D.; Letourneur, Y.; et al. Climate Warming, Marine Protected Areas and the Ocean-Scale Integrity of Coral Reef Ecosystems. PLoS ONE 2008, 3, e3039. [CrossRef] [PubMed] 
57. Carpenter, K.E.; Abrar, M.; Aeby, G.; Aronson, R.B.; Banks, S.; Bruckner, A.; Chiriboga, A.; Cortés, J.; Delbeek, J.C.; DeVantier, L.; et al. One-Third of Reef-Building Corals Face Elevated Extinction Risk from Climate Change and Local Impacts. Science 2008, 321, 560-563. [CrossRef]

58. Cowburn, B.; Samoilys, M.A.; Obura, D. The Current Status of Coral Reefs and Their Vulnerability to Climate Change and Multiple Human Stresses in the Comoros Archipelago, Western Indian Ocean. Mar. Pollut. Bull. 2018, 133, 956-969. [CrossRef]

59. Jaleel, A. The Status of the Coral Reefs and the Management Approaches: The Case of the Maldives. Ocean Coast. Manag. 2013, 82, 104-118. [CrossRef]

60. Nepote, E.; Bianchi, C.N.; Chiantore, M.; Morri, C.; Montefalcone, M. Pattern and Intensity of Human Impact on Coral Reefs Depend on Depth along the Reef Profile and on the Descriptor Adopted. Estuar. Coast. Shelf Sci. 2016, 178, 86-91. [CrossRef]

61. Cowburn, B.; Moritz, C.; Birrell, C.; Grimsditch, G.; Abdulla, A. Can Luxury and Environmental Sustainability Co-Exist? Assessing the Environmental Impact of Resort Tourism on Coral Reefs in the Maldives. Ocean Coast. Manag. 2018, 158, 120-127. [CrossRef]

62. Pancrazi, I.; Ahmed, H.; Cerrano, C.; Montefalcone, M. Synergic Effect of Global Thermal Anomalies and Local Dredging Activities on Coral Reefs of the Maldives. Mar. Pollut. Bull. 2020, 160, 111585. [CrossRef]

63. Bessell-Browne, P.; Negri, A.P.; Fisher, R.; Clode, P.L.; Duckworth, A.; Jones, R. Impacts of Turbidity on Corals: The Relative Importance of Light Limitation and Suspended Sediments. Mar. Pollut. Bull. 2017, 117, 161-170. [CrossRef]

64. Bessell-Browne, P.; Fisher, R.; Duckworth, A.; Jones, R. Mucous Sheet Production in Porites: An Effective Bioindicator of Sediment Related Pressures. Ecol. Indic. 2017, 77, 276-285. [CrossRef]

65. Jones, R.; Bessell-Browne, P.; Fisher, R.; Klonowski, W.; Slivkoff, M. Assessing the Impacts of Sediments from Dredging on Corals. Mar. Pollut. Bull. 2016, 102, 9-29. [CrossRef]

66. Ricardo, G.F.; Jones, R.J.; Nordborg, M.; Negri, A.P. Settlement Patterns of the Coral Acropora Millepora on Sediment-Laden Surfaces. Sci. Total Environ. 2017, 609, 277-288. [CrossRef] [PubMed]

67. Berry, K.L.E.; Hoogenboom, M.O.; Brinkman, D.L.; Burns, K.A.; Negri, A.P. Effects of Coal Contamination on Early Life History Processes of a Reef-Building Coral, Acropora Tenuis. Mar. Pollut. Bull. 2017, 114, 505-514. [CrossRef] [PubMed]

68. Bessell-Browne, P.; Negri, A.P.; Fisher, R.; Clode, P.L.; Jones, R. Cumulative Impacts: Thermally Bleached Corals Have Reduced Capacity to Clear Deposited Sediment. Sci. Rep. 2017, 7, 2716. [CrossRef]

69. Fitt, W.K.; McFarland, F.K.; Warner, M.E.; Chilcoat, G.C. Seasonal Patterns of Tissue Biomass and Densities of Symbiotic Dinoflagellates in Reef Corals and Relation to Coral Bleaching. Limnol. Oceanogr. 2000, 45, 677-685. [CrossRef]

70. Porter, J.W.; Fitt, W.K.; Spero, H.J.; Rogers, C.S.; White, M.W. Bleaching in Reef Corals: Physiological and Stable Isotopic Responses. Proc. Natl. Acad. Sci. USA 1989, 86, 9342-9346. [CrossRef] [PubMed]

71. Fisher, R.; Bessell-Browne, P.; Jones, R. Synergistic and Antagonistic Impacts of Suspended Sediments and Thermal Stress on Corals. Nat. Commun. 2019, 10, 2346. [CrossRef] [PubMed]

72. Hill, J.; Loder, J. Reef Check Australia Survey Methods; Reef Check Foundation Ltd.: Queensland, Australia, 2013 ; p. 18.

73. R Core Team. R: A Language and Environment for Statistical Computing; R Foundation for Statistical Computing: Vienna, Austria, 2020.

74. Burnham, K.P.; Anderson, D.R. Model Selection and Multimodel Inference: A Practical Information-Theoretic Approach, 2nd ed.; Springer: New York, NY, USA, 2002. [CrossRef]

75. Brooks, M.E.; Kristensen, K.; van Benthem, K.J.; Magnusson, A.; Berg, C.W.; Nielsen, A.; Skaug, H.J.; Mächler, M.; Bolker, B.M. GlmmTMB Balances Speed and Flexibility Among Packages for Zero-Inflated Generalized Linear Mixed Modeling. R J. 2017, 9 , 378-400. [CrossRef] 